\title{
The Development of Four Leading Principles of the Convention on the Rights of the Child in Vietnam's Juvenile Justice
}

\author{
DUC NGUYEN*
}

\section{Introduction}

Children, the future of mankind, are vulnerable to many external factors. They need special care and safeguards due to their physical and mental immaturity, and the general society 'owes to the child the best it has to give.' An effective juvenile justice system is an important part of what society owes to all children. The juvenile justice system was established in several Western countries in the early twentieth century. The idea for a separate system of justice is based on the legal doctrine of parens patriae. That is, the state is the ultimate guardian of children. ${ }^{2}$

Four leading principles in the United Nations Convention on the Rights of the Child (CRC), including Article 2 (Non-discrimination), Article 3 (Best interests of the child), Article 6 (The Right to Life, Survival and Development), and Article 12 (The Right to be Heard), must be observed in any areas of law dealing with children. In the ad-

* MP, Legal Researcher at Institute of State and Law, Vietnam Academy of Social Sciences, Hanoi, Vietnam. This paper builds on the author's Master thesis written for a Master's degree on Human rights at the Norwegian Centre for Human Rights, University of Oslo. The author is in debt to Professor Gentian Zyberi (University of Oslo) for his valuable comments.

1 The Preamble of the Declaration of the Rights of the Child; The Preamble of CRC; See Freeman, The Limits of Children's Rights in Ideologies of Children's Rights, eds. Freeman and Veerman (Martinus Nijhoff Publishers, 1994) pp. 29-46; See also Rogers and Roche, Children's Welfare and Children's Rights: A Practical Guide to the Law (Hodder and Stoughton, 1994); Van Bueren, The International Law on the Rights of the Child (Martinus Nijhoff Publishers, 1995).

2 Jensen and Jepsen (eds.), Juvenile Law Violators, Human Rights, and the Development of New Juvenile Justice Systems (Hart Publishing, 2006) p. 2.

This is an Open-access article distributed under the terms of the Creative Commons Attribution 3.0 Unported License (http://creativecommons.org/licenses/ by/3.0/, permitting all use, distribution, and reproduction in any medium, provided the original work is properly cited. 
ministration of juvenile justice, States Parties are required to apply systematically these general principles to handle juvenile offenders. ${ }^{3}$ The CRC Committee has elaborated the implications of four leading principles in the administration of juvenile justice in its General Comment No. 10 (GC No. 10). At international level, several relevant international instruments are of complementary nature to the CRC, such as the 'UN Standards and Norms in Juvenile Justice. This compendium consists of three more documents, namely The Standard Minimum Rules for the Administration of Juvenile Justice (Beijing Rules) ${ }^{4}$, The Guidelines for the Prevention of Juvenile Delinquency (Riyadh Guidelines) ${ }^{5}$, and UN Rules for the Protection of Juveniles Deprived of Their Liberty (Havana Rules) ${ }^{6}$.

Vietnam was the first Asian country to ratify the Convention on the Rights of the Child (CRC) in 1990. Ever since, Vietnam has made significant efforts in the process of realising and safeguarding children's rights. ${ }^{7}$ To examine and assess the development and compatibility of Vietnam justice regulations, the author will focus on the two most recent and prominent laws in Vietnam's juvenile justice. These laws are the 1999 Penal Code (Amended 2009) and the 2003 Criminal Procedure Code (hereinafter referred to as Old Codes), which are currently still in effect, in addition to the 2015 Penal Code (PC) and the 2015 Criminal Procedure Code (CPC) (hereinafter referred to as New Codes), which were recently approved by the National Assembly and will take effect at the end of 2016.

Before further reading, there is a need to clarify the word 'offender. The word indicates all juveniles who are alleged to have committed or who have been found to have committed an offence. ${ }^{8}$ It covers suspects, arrestees, detainees, accused, defendants at pre-judgment stages, as well as juvenile inmates after a judgment of a court of law have taken effect.

\section{Child in the CRC and in the Context of Vietnam}

As provided under Article 1 of the CRC, generally a child is defined as a human being below the age of eighteen. States are flexible to adopt this definition if their laws attain an earlier age. The CRC Committee and other organisations, however, increasingly en-

3 CRC Committee, General Comment No. 10 (CRC/C/GC/10, 2007) para. 5.

4 http://www.ohchr.org/Documents/ProfessionalInterest/beijingrules.pdf [Last accessed: 20th December 2016]

5 http://www.un.org/documents/ga/res/45/a45r112.htm [Last accessed: 20th December 2016]

6 http://www.un.org/documents/ga/res/45/a45r113.htm [Last accessed 20th December 2016]

7 Comment on the Rights of the Child, Vietnam, National Report on the Implementation of the Convention on the Rights of the Child 1993 - 1998 (U.N. Doc. CRC/C/65/Add.20, 2002) para. 66.

$8 \quad$ Principle 2.2(c) of the Beijing Rules. 
courage states parties to ensure the rights for every person below the age of $18 .{ }^{9}$ Notably, juveniles are not defined under the CRC. In brief, the CRC, in respect of juvenile justice, implies that the right-holders should be specially treated, as they still have not reached the age of maturity.

Under the 2004 and 2016 Law on Child Protection, Care and Education of Vietnam, a 'child' (tre em in Vietnamese) indicates any person below the age of 16. Meanwhile, the concept of 'juvenile' (nguoi chua thanh nien) means any person, regardless of sex, aged below 18. ${ }^{10}$ Age limitation to categorise a child under Vietnamese law is in conformity with CRC and relevant instruments. However, there is a difference in the use of each of these terms in Vietnam context. The child (tre em) is the term employed in legal documents that prescribe general issues of child protection and care. In other words, the use of the term tre em aims to emphasise the vulnerability and rights of children. The term 'juvenile' (nguoi chua thanh nien), on the other hand, is more frequently used in normative documents that specify his or her legal rights, obligations and duties towards others. ${ }^{11}$ This type of thinking might get in the way of handling the best interest of children when they are on trial.

\section{Four Leading Principles in the CRC}

\subsection{Non-Discrimination}

The right of non-discrimination is a human right: the individual adolescent or child is the right holder, meanwhile the state party is the corresponding duty bearer. This right is considered an umbrella right to add protection to the sectorial rights in CRC. ${ }^{12}$ Article

9 CRC Committee, General Comment No. 14 on the Rights of the Child to Have His or Her Best Interests Taken as a Primary Consideration, CRC/C/GC/14 (2013); General Comment No. 4 on Adolescent Health and Development in the Context of the Convention on the Rights of the Child, CRC/C/GC/4 (2003).

10 Dieu 7, Sac Lenh 97-SL, 22/5/1950 cua Chu Tich Chinh Phu ve Sua Doi mot so Quy Le va Che Dinh trong Dan Luat [Article 7, Edict 97-SL dated 22 May 1950, issued by the President of the Government on Amending a Number of Rules and Regulations in the Civil Law]; Vietnam Civil Code of 1995 and 2005.

11 See Civil Code of 2005, Civil Procedure Code of 2004, The Law on Handling of Administrative Violations of 2012.

12 Abramson, A Commentary on the United Nations Convention on the Rights of the Child: Article 2 The Right of Non-Discrimination (Martinus Nijhoff Publishers, 2008) p. 7. 
2 of CRC expands the forbidden grounds of adverse distinction more than any other human rights treaties. ${ }^{13}$

The right of non-discrimination has a particular aspect in the administration of juvenile justice. It is statistically shown that children in conflict with the law who have a background of poverty, homelessness, ethnic minorities or from other vulnerable groups, are usually victims of discrimination. ${ }^{14}$ The CRC Committee affirms that States Parties are under obligation to take all necessary measures to ensure that all children in conflict with the law are treated equally. ${ }^{15}$ Furthermore, to guarantee an equal treatment under the law for children and adults, States Parties are also required to factor in children's psychological immaturity and behavioral problems to ensure that 'any conduct not considered an offence or not penalized if committed by an adult is not considered an offence and not penalized if committed by a young person ' 16

\subsection{The Best Interest of the Child}

Despite its vagueness, the best interest principle plays a crucial role in realising and implementing children's rights. ${ }^{17}$ The principle has three roles. Firstly, in the situation where different interests are at stake, the best interest of the child should be of first consideration. In other words, it would be 'an aid to construction, as well as an element which needs to be taken fully into account in implementing other rights. ${ }^{18}$ Secondly, where a legal provision is vague and open to different interpretations, the interpretation, which is most beneficial and fruitful for children, should take priority. The last fold suggests that 'in all

The United Nations Charter has four grounds (race, sex, religion, language); ICCPR and ICESCR add six more (color, political or other opinion, national or social origin, property, birth, other status), meanwhile the CRC adds two more (ethnic origin, and disability).

14 Goldson and Muncie, Towards a Global Child Friendly Juvenile Justice?, 40(1) International Journal of Law, Crime and Justice, (2012) pp. 47-64, at 55.

$15 \quad$ GC No. 10 para. 6.

16 GC No. 10 para. 8; Article 56 of the Riyadh Guidelines.

17 Rehman, International Human Rights Law, $2^{\text {nd }}$ ed. (Pearson, 2010) pp. 564-565; Freeman, A Commentary on the UN Convention on the Rights of the Child, Article 3 The Best Interest of The Child (Martinus Nijhoff Publishers, 2007); in some case law, this principle is recognised as a principle of customary international law, see more Beharry v. Reno, 181 F. Supp 2d pp. 584, 603-605 (E.D.N.Y. 2002) discussed in Aleinikoff and Chetail, Migration and International Legal Norms (Asser Press, 2003) p. 101.

18 Reece, The Paramountcy Principle: Consensus or Construct?, 49 Current Legal Problems (1996) p. 16. 
matter not governed by positive rights in the Convention, Article 3(1) will be the basis for evaluating the laws and practices of States Parties.' ${ }^{19}$

In respect of the administration of juvenile justice, the best interest of the child should be of primary consideration. The protection of this interest means, for instance, that the traditional objectives of criminal justice, such as repression and retribution, must give way to rehabilitation and restorative justice objectives in dealing with child offenders. ${ }^{20}$ Furthermore, the best interest principle covers lesser culpability under the penal law and alternative measures and procedures specifically dealing with juvenile offenders. The low minimum age of criminal responsibility is a concern when the interpretation of the best interest principle takes place. ${ }^{21}$

\subsubsection{Minimum Age of Criminal Responsibility (MACR)}

MACR is a crucial issue that troubles legislators in order to strike the balance between the maintenance of public order and the protection of children's rights. The MACR denotes the lowest age at which a person may be subject to criminal liability for breaking the penal law. Defining the MACR is fundamentally subjective and arbitrary since there is no uniform and consistent formula. ${ }^{22}$ In state practice, the MACR varies and ranges 'from a very low level of age 7 or 8 to the commendable high level of age 14 or $16^{2} .^{23}$

Article 40(3) of CRC obliges States Parties to establish a minimum age, below which children shall be presumed not to have the capacity to violate the penal law, however, a specific minimum age is left open for States to decide. Rule 4 of Beijing Rules recommends that the departure point of MACR shall not be fixed at too low an age level. In addition, authorities must take into account the facts of emotional, mental and intellectual immaturity of children. The CRC Committee complements the Beijing Rules by stating

19 Alston, The Best Interests Principle: Towards a Reconciliation of Culture and Human Rights in Children's Rights vol 2, ed. Freeman (Ashgate/Dartmouth 2004) pp. 183-197.

20 GC No. 10 para. 10; For restorative justice, see more Lemley, Designing Restorative Justice Policy: An Analytical Perspective in Criminal Justice Policy Review 12(1) (2001) pp. 43-65, at 43; Daly, Restorative Justice: A Real Story, Punishment and Society 4(1)(2002) pp. 55-79, at 55; Galaway and Hudson (eds), Restorative Justice: International Perspective (Criminal Justice Press 1996) pp. 17-36.

21 CRC Committee, Concluding Observation: China (CRC/C/15/Add. 56, 1996) pp. 13; Kuwait (CRC/C/15/Add. 96, 1998) para. 15; Egypt (CRC/C/15/Add.5, 1993) para. 14.

22 Tomasevski (eds.), Children In Adult Prisons: An International Perspective (Frances Pinter Publishers 1986) pp. 5 and 57.

23 GC No. 10 para. 30. 
that a MACR below the age of 12 years is not regarded as internationally acceptable and therefore goes against the principle of best interest of the child. ${ }^{24}$

\subsection{The Right to Life, Survival and Development}

This principle requires an interpretation of Article 6 to take into consideration all the other human rights enshrined in CRC. ${ }^{25}$ It is recognised that delinquency has a very negative impact on the child's development. ${ }^{26}$ Therefore, States Parties should take initiatives to develop effective national policies and programmes to respond to juvenile delinquency in ways that support the child's development. Some initiatives may for instance be development of diversion and intervention measures and limited use of deprivation of liberty of children. This is to ensure that children are able to easily reintegrate into society, and furthermore, to refrain from inflicting negatively on children's mental and physical health.

Death penalty against juveniles is explicitly prohibited under Article 6(5) of ICCPR and Article 37(a) of CRC. Admittedly, the prohibition on imposing the death penalty on juveniles constitutes customary international law and, thus, all states are under the obligation to observe it. ${ }^{27}$ In contrast, life imprisonment is not strictly prohibited. The imposition of the sentence is only forbidden in Article 37(a) of CRC if the State does not provide the child a possibility of conditional release.

\subsection{The Right to Be Heard}

This is not only a right, but also the leading principle - running like a thread throughout the juvenile justice process, from the pre-trial stage to court hearings and implementation of the imposed measures. The gravity of the right to be heard is important in the realisation of children's rights as stated by the CRC Committee in its general comment

\footnotetext{
$24 \quad$ GC No. 10 paras. 32- 33.

25 Nowak, A Commentary on the UN Convention on the Rights of the Child, Article 6 The Right to Life, Survival and Development (Martinus Nijhoff Publishers, 2005) p. 2.

26 GC No. 10 para. 11.

27 Human Rights Committee, UN Doc. HRI/GEN/1/Rev.7, 24/52 (1994) pp. 8; See e.g. the landmark judgment of the South African Constitutional Court of 6 June 1995 in State v. Makwanyane and Mchunu, Case No. CCT/3/94. On the trends towards abolition see Schabas, The Abolition of the Death Penalty in International Law, $3^{\text {rd }}$ ed. (Cambridge University Press 2002); Nowak, UN Covenant on Civil and Political Rights: CCPR Commentary, $2^{\text {nd }}$ ed. (N.P. Engel Publishers 2004), pp. 133-138 and 168-172.
} 
No. $12^{28}$. This right has a connection to other general principles, and particularly is interdependent with the principle of best interests of the child. ${ }^{29}$

The right to be heard is fundamental for a fair trial, and might be implemented either directly by the child or through his representative or an appropriate body in a manner consistent with the procedural rules of national law. The CRC Committee has noted that 'the voices of children involved in juvenile justice system are increasingly becoming a powerful force for improvements and reform, and for the fulfilment of their rights. ${ }^{30}$ Therefore, due weight must be given to the voices of children in accordance with their age and maturity, throughout every stage of the process of juvenile justice. This requires authorities to not only be attentive when dealing with juvenile offenders, but also to possess knowledge, understanding and competence in handling children who are in conflict with the law.

\section{Vietnam's Recognition of CRC Principles}

\subsection{Non-discrimination}

The principle of non-discrimination has long been recognised under the Vietnamese legal system. ${ }^{31}$ Article 16 of the 2013 Constitution of Vietnam recognises that everyone is equal before the law. Both the Old and New PC and CPC have embodied this general principle by stating that all persons are equal before the law and the court of law regardless of ethnicity, sex, religion, social status and class. ${ }^{32}$

Article 68 of the Old PC provides that the responsibility of juvenile offenders shall be subject to specific regulations in Chapter X. However, such regulations do not provide any new offences applied solely to juvenile offenders, but lay out general principles in handling juvenile offenders. This means Vietnam penal law does not establish status offences applied to a juvenile. In other words, Vietnam's juvenile justice guarantees the equal treatment between an adult and a young person, and is in conformity with CRC standards in this respect. The same provision can be found in Article 90 of the New PC.

In practice, however, it is continuously shown in statistics that the majority of juvenile offenders are in special circumstances, such as street, homeless children, and

28 CRC Committee, GC No. 12: The Right of the Child to Be Heard (CRC/C/GC/12, 2009).

29 GC No. 12, para. 68-79.

30 GC No. 10 [12]; UNICEF, Implementation Handbook for the Convention on the Rights of the Child (2002) p. 166.

31 This principle was enshrined in Article 6 and 7 The Constitution of the Democratic Republic of Vietnam of 1946, Article 3 of the Penal Code of 1999.

32 Article 3(2) and 5 of the Old and New PC, Article 5 and 9 of the Old and New CPC respectively. 
the number is climbing. ${ }^{33}$ This might pose a challenge to Vietnamese professionals and personnel involved in the administration of juvenile justice, as well as policy-makers in handling and curbing juvenile delinquency.

\subsection{The Best Interest of the Child}

Both the Old and New PC provide general principles on the handling of juvenile offenders. Generally, the treatment must be based on age and maturity, as well as the understanding of the juvenile offender and of the seriousness of offences committed against society. The Old PC does not explicitly provide the principle of best interest, however, Article 69(1) gives way to rehabilitation and restorative justice objectives by stating that principles of handling juvenile offenders mainly aim to help them repair the harms done and avoid future deviation. Article 91(1) and 414(1) of the New PC and CPC reaffirm this principle. Moreover, it is even pushed further in that the handling of juvenile offenders must ensure 'the best interest of offenders aged under 18 years'.

Nonetheless, the new provision might become confusing and problematic when it comes to interpretation. What does it mean by 'the best interest of offenders aged under 18 years'? Other than the best interest of the child in the CRC, there is no such a principle under either international law or Vietnamese national law. ${ }^{34}$ It appears that Vietnamese lawmakers imply the CRC principle of best interest of the child with a minor modification because they are seemingly reluctant in adopting the concept of a child aged below 18 years. ${ }^{35}$ It has two implications. On the one hand, with the realisation of the vulnerability of children, Vietnam has recognised the best interest of children not only in general fashion, but also shed light on the justice system directly dealing with children. This fact indicates that Vietnam is fully aware of its international commitment under the $\mathrm{CRC}$ and is willing to translate it into practice. The principle might be helpful for procedure-conducting persons when looking at the choice of appropriate measures applicable to juveniles, and is thus consistent with Article 3 of CRC. On the other hand, this might also raise a question with respect to the Vietnamese definition of the child. There are many vulnerable groups of people, such as women and disabled persons, none of them,

33 Bui, Toi Pham Vi Thanh Nien va Giai Phap Khac Phuc [Juvenile Offenders and Measures to Address], Link: http://tcdcpl.moj.gov.vn/qt/tintuc/Pages/xay-dung-phap-luat.aspx?ItemID=164, [Last accessed: July 21st 2016] Ngo, Thuc Trang Toi Pham Vi Thanh Nien: Nguyen Nhan va Giai Phap [The Situation of Juvenile Delinquency: Causes and Measures], Link: hocvientuphap.edu. vn/desktops/news/download.aspx?id=284, [Last accessed: July $21^{\text {st }} 2016$ ].

34 Article 5.3 of the 2016 Law on Care, Education and Protection of Children stipulates the principle of best interest of the child, not of 'those under 18 years'.

35 The Current and New Law on Care, Education and Protection of Children provide that a child is a person aged below 16 years. 
however, possess this type of privilege. The best interest of children stems from their vulnerability, fragility and special needs and is reserved to them only. The best interest of 'persons under 18 years' in the New PC implicitly shows that Vietnamese lawmakers have seen young people below 18 years as children. As a result, in their eyes, people under 18 years of age should be considered children. This way of thinking might turn around and challenge the old concept of the child in Vietnam's New Law on Children.

\subsubsection{Minimum Age of Criminal Responsibility (MACR)}

In the general justice system, the PC and CPC regulate matters relating to crimes, punishments and relevant procedures. The crimes are categorised into four different types based on their severity and nature: less serious (the ceiling of punishment is imprisonment for up to 3 years), serious (up to 7 years), very serious (up to 15 years) and severely serious (from 15 years to life imprisonment or death penalty).

Article 12 of the Old PC provides that persons aged 16 or older shall bear penal liability for all crimes they commit; while those aged 14, but under 16 shall be held criminally responsible for very serious crimes intentionally committed or for severely serious crimes. Persons below 14 presumably do not have the capacity to violate penal law, hence the MACR in the Vietnam justice system is 14 years. This current provision is aligned with the international standards set out by CRC.

\begin{tabular}{|c|c|c|c|c|}
\hline Age/Crimes & Less Serious & Serious & Very Serious & Severely Serious \\
\hline Under 14 & Exemption & Exemption & Exemption & Exemption \\
\hline $\mathbf{1 4}-\mathbf{1 6}$ & $\begin{array}{c}\mathrm{AH} \\
\text { Administrative } \\
\text { Handling where } \\
\text { Administrative Laws } \\
\text { are applicable to } \\
\text { handle the violations }\end{array}$ & $\mathrm{AH}$ & $\begin{array}{c}\mathrm{CH} \\
\text { Criminal Handling } \\
\text { (RS) } \\
\text { (Reduced Sentence) }\end{array}$ & CH (RS) \\
& & & & \\
\hline $\mathbf{1 6 - 1 8}$ & $\mathrm{CH}(\mathrm{RS})$ & $\mathrm{CH}(\mathrm{RS})$ & $\mathrm{CH}(\mathrm{RS})$ & $\mathrm{CH}(\mathrm{RS})$ \\
\hline $\mathbf{1 8}$ or older & $\mathrm{CH}$ & $\mathrm{CH}$ & $\mathrm{CH}$ & $\mathrm{CH}$ \\
\hline
\end{tabular}

Source: The New PC; The 2012 Law on Handling Administrative Violations

There were concerns regarding crimes committed by juveniles that would prompt public outrage, such as the Ngoc Bich Jewelry case, where a juvenile intentionally killed 
an entire family to rob the property ${ }^{36}$ Furthermore, it is statistically shown that the number of crimes committed by juveniles have recently been rampant. ${ }^{37}$ Such concerns led to suggestions to lower the MACR and place stricter criminal penalties upon juveniles. ${ }^{38}$

Besides, some debate that Article 12 of the Old PC, regarding penal liability of persons aged from 14 to 16 , is too general and has not manifested the humanitarian policy towards the handling of juvenile offenders or embodied the spirit of CRC. ${ }^{39}$ Meanwhile, the phrase "very serious crimes committed intentionally or severely serious crimes" is far broad and unclear as it essentially covers all crimes.

Eventually, the New PC is amended in particular ways. Firstly, it is contended that serious cases, like Le Van Luyen, are rather rare, thus it is not necessary to impose more stringent regulations on juvenile offenders. Hence, the MACR from 14 years under the New PC remains unchanged. ${ }^{40}$ Those aged from 16 years are responsible for all types of crimes.

Secondly, persons aged from full 14 years to below 16 shall be held criminally responsible for two specific groups of crimes. The first group is certain crimes regardless of the seriousness of such crimes, namely: murder, intentional infliction of harm onto others, rape, raping persons aged under 16 years, forcible sexual intercourse with persons aged from 13 to under 16 years, property robbery and kidnapping to appropriate property. The second group includes very serious crimes committed intentionally or severely serious crimes, namely: (i) forcible sexual intercourse; illicit trading in persons aged under 16; (ii) plundering property, stealing property, property robbery by snatching or intentional vandalism of property; (iii) illegally producing, trading in, stockpiling, transporting or appropriating narcotic drugs; (iv) organising and participating in illegal motor races; (v) producing, trading in or giving away devices, gadgets and software for illegal purpose of

36 Y An 18 Nam Tu Doi voi Le Van Luyen [Le Van Luyen Sentenced 18 Years Imprisonment], VnExpress Mar 30 2012, Link: http://vnexpress.net/tin-tuc/phap-luat/y-an-18-nam-tu-voi-levan-luyen-2227141.html, [Last Accessed: July 12 2016].

37 Tong Cuc Canh Sat PCTP, Bao Cao Tinh Hinh, Ket Qua Cong Tac Phong, Chong Toi Pham Nam 2011, [Report on the Implementation of Preventing and Combating Crime of 2011] (Ministry of Public Security, 2011); Vietnam Lawyers Association (VLA) and UNICEF Vietnam, Report of the Proposed Amendments to the Penal Code and the Criminal Procedure Code (Internally Circulated Material) (UNICEF Seminar, 2015) pp. 1-2.

38 See VLA and UNICEF Vietnam 2015, p. 2-3; See Hung, Giam Tuoi Vi Thanh Nien de Chong Toi Pham Tre Em [Decreasing the Juvenile Age to Prevent Child Crimes], VN Media (online), Nov 12012 http://www.tinmoi.vn/giam-tuoi-vi-thanh-nien-de-chong-toi-pham-tre-011096568.html, [Last accessed: July 2, 2016]; Thuy, Can Nhac Tang Hinh Phat doi voi Nguoi Pham Toi Chua Thanh Nien [Consideration of Increasing Harsher Punishment Possible Applied to Juvenile Offenders], Luat and Hoi (online), 2013 http://dantri.com.vn/phap-luat/can-nhac-tang-hinh-phat-voi-nguoipham-toi-chua- thanh-nien-718153.htm, [Last accessed: July 2, 2016].

$39 \quad$ VLA and UNICEF Vietnam 2015 p. 3.

$40 \quad$ Article 90 New PC. 
use; (vi) terrorism; destruction of national security infrastructures; illicit manufacturing, stockpiling, transporting, using, trading in or appropriating military weapons and technical military devices. ${ }^{41}$

Both Old and New PC provisions are applicable at the time the crime was committed. In other words, the legal substance and procedures pertaining to juveniles are still applicable to adults if they were juvenile at the time they committed a crime. Among many efforts, the Supreme Court and other authorities have issued guidelines in order to clarify the age of an offender in cases where he has no records of exact date of birth. ${ }^{42}$ The New CPC supplements a new provision specifically dealing with the method for age clarification of juvenile accused and victims ${ }^{43}$ Such provisions have dispelled the vagueness and paved the way for legal application, and are fully in accordance with the CRC standards regarding the MACR.

In practice, the Appellate Court overruled a first-instance judgment because the defendant had not reached the age of criminal responsibility at the time of commission of the crime. ${ }^{44}$ Similarly, the Appeal Court revoked the death penalty on an offender since he had not reached 18 years old when the crime was committed. ${ }^{45}$

\subsection{The Right to Life, Survival and Development}

In respect of the right to life, survival and development of the child, it is conceded by Vietnamese scholars that custodial penalties are at a high risk of harming the ability of juveniles to rehabilitate and re-integrate into the community. ${ }^{46}$ Therefore, the criminal handling of juvenile offenders must be done with deliberation. Charges for criminal responsibility of juvenile offenders are conducted in cases of necessity only. However, Article 69(4) of the Old PC suggests otherwise: 'Courts, if deeming it unnecessary to impose penalties on juvenile offenders, shall apply one of the judicial measures'. In other words, the court shall consider penalties first, and if they find it unnecessary to do so, they shall apply judicial measures which are substitutes to penalties and more humane towards the convicted. This provision goes against the spirit of CRC, which regards judicial proceedings as inevitable and the deprivation of children's liberty as the last resort only. The same

$41 \quad$ Article 12(2) New PC.

42 Official Dispatch 81/2002/TANDTC and the Joint Circular 01/2011/TTLT-VKSTC-TANDTCBCA-BTP-BLDTBXH on Juvenile Cases.

43 Article $471 \mathrm{New}$ CPC.

44 Judgment No xxx/2014/HSST issued by the Court of XXX city. (The number of the judgment and the name of the city is coded due to Vietnamese internal regulations).

45 Le, Thoat An Tu Sau Hai Lan bi Tuyen Tu Hinh [Espaced Death from Two Death Sentences], Thanh Nien online, Dec 162013.

$46 \quad$ VLA and UNICEF 2015, p. 5. 
stipulation can be found in Article 307(2) of the Old CPC with regard to Jury Panels' verdict. $^{47}$

In this respect, a new amendment to the New PC provides that the courts only impose penalties on juvenile offenders in cases where other measures are proven ineffective for educational and deterrent purposes. This amendment will be helpful in guiding courts and judges when considering measures applicable to juvenile offenders. Ironically, Article 423(6) of the New CPC, nevertheless, still retains the old stipulation that 'the Jury Panels, if deeming it unnecessary to impose penalties on juvenile offenders, shall apply educational measure in reformatory school'. This provision once again follows the traditional objectives of criminal justice, that is a retributive and punitive approach, and definitely fails to align with the New PC provision or the CRC standards.

This is another confusion and contradiction between the new PC and CPC when it comes to the practical application of the law. The New CPC stipulates that the Jury Panel shall consider criminal penalties in the first place. Generally speaking, a Jury Panel is always established in criminal cases unless it is a summary procedure, which is very rare. On the other hand, the term 'Courts' employed under the New PC leads to a very general understanding, which might refer to the fact that a judge or a jury panel shall prioritise monitoring and educational measures. However, the author proposes that in such cases, applying the principle of best interest of the child can help remedy the problem. As manifested above, if legal provisions suggest different understandings, the provision that is most fruitful and beneficial for the child shall take precedence. In this case it is the New PC provision prioritising other alternatives to criminal handling measures.

In Vietnam, it has long been recognised legally that death penalty and life imprisonment shall not be imposed on juvenile delinquents. This rule has been embodied under Article 69(5) and 91(5) of the Old and New PC respectively. Moreover, the Courts shall always consider reducing the punishment on juvenile offenders.

\subsubsection{Interventions and Diversions}

As previously mentioned, the use of deprivation of liberty, including pre-trial detention and post-trial incarceration, has very negative consequences for the child's harmonious development and seriously hampers his or her reintegration into society and must consequently be restricted. As a result, states are encouraged to adopt two types of interventions and diversions, namely measures without resorting to judicial proceedings and measures in the context of judicial proceedings.

47 Note that the concept of 'Jury Panel' in Vietnam justice system is quite distinct. A Jury Panel in Vietnam comprises three to five members, including one to three judges, and jurors who have equal say on all matters. Decisions are rendered on the majority basis. 


\subsubsection{Measures without resorting to judicial proceedings}

Article 69 of the Old PC provides that juvenile criminals may be exempt from criminal responsibility if they commit less serious crimes or serious crimes with extenuating circumstances, which causes no severe damage, and their families or relevant organisations guarantee to supervise and educate them.

In Vietnam's justice system, neither the judge nor the jury panel has the power to divert child offenders from a criminal proceeding. Even if there is clear evidence that the child offender can be exempt from criminal responsibility, the case cannot be dropped by the judge, and he or she has to carry on until a judgment is rendered. Generally, a child offender still has to go through the entire criminal procedural process.

Only courts have the power to apply the measure of supervision and education at ward or commune. However, this measure is considered ineffective to address juvenile crimes. During the period from 2007 to 2013, only 52 juvenile offenders were sent back for education at their ward or commune. ${ }^{48}$ Firstly, supervision and education at the ward or commune is only considered in cases of less serious or serious crimes. Hence, the scope of this measure is very limited as it does not extend to those between 14 years and 16 years of age, who intentionally commit very serious crimes or severely serious crimes. Secondly, the attitude of judges towards handling criminal cases is still prone to the retributive or punitive approach. ${ }^{49}$ Thirdly, the roles of families, organisations, and agencies in supervision and education of juvenile offenders are very formalistic. Supportive services for juvenile offenders, such as consultation, tutorship and training have been little mentioned in the law.

The New PC has broadened the types and scope of application of supervision and education measures. Three types of measures are introduced, namely chiding, community-based conciliation, and education at ward or commune. Authorities empowered to apply such measures include not only courts, but also investigating bodies and public procurators. This provision indicates that, at different stages of the criminal process, different competent actors can divert the child offender from judicial proceedings through determining other applicable measures. The role of the police and the public procurators is properly enhanced, giving them more powers to divert child offenders out of criminal process. The amendment is in total accordance with the spirit of the CRC.

48 Pham, The Rights of The Child in Judicial Sector in Vietnam: Compliance with International Legal Standards, Doctor of Philosophy Thesis, Faculty of Law, Humanities and the Arts, University of Wollongong, 2015, http://ro.uow.edu.au/theses/4524, p. 195.

$49 \quad$ Ibid, p.196. 


\subsubsection{Measures in the context of judicial proceedings}

Depending on the nature and seriousness of the crimes and on the personal details of the child offenders, non-custodial measures can be applied during the trial, including (a) ban on travel out of place of residence, (b) guarantee, and (c) deposit of money or valuable property as bail. The first measure requires the child offenders to pledge in written form, with the presence of their parents or legal representatives, to abide the law and appear where there is a court subpoena. ${ }^{50}$ Guarantee and bail, deterrent measures alternative to temporary detention, requires at least two relatives of the child offenders or organisations to which they are a member. Such relatives or organisations must have good conducts and qualities and pledge not to allow the offenders to continue committing offences. Furthermore, they must ensure the offender's appearance in response to the summons of investigating bodies, procuracies, or subpoenas of courts. ${ }^{51}$ Case studies indicate that the measures 'ban on travel out of place of residence' and 'guarantee' are applied frequently. ${ }^{52}$

In the general justice system, if an offender is found guilty, the judge may apply one of the following penalties: seven principal penalties (including warning, fine, non-custodial reform, expulsion, termed imprisonment, life imprisonment and death penalty), and seven additional penalties (including ban from holding certain posts, practicing occupations or doing certain jobs, ban on residence, probation, deprivation of some civic rights, confiscation of property, fine, ${ }^{53}$ and expulsion $\left.{ }^{54}\right) .{ }^{55}$ Those who suffer from mental illness or disorder at the time of commission of the crime, shall undergo mandatory medical treatment in a psychiatric institution.

For juvenile offenders, Article 71 of the Old PC provides: 'Juvenile offenders shall be subject to only one of following penalties for each crime: 1 . Warning; 2 . Fine; 3 . Non-custodial reform; 4. Termed imprisonment.'

The first two penalties are applicable for less serious crimes, and non-custodial reform is for less serious or serious crimes. As a result, termed imprisonment is the only alternative for the court to apply against those aged from 14 to below 16 years, who bear criminal responsibility for very serious crimes committed intentionally or for severely serious crimes. This provision does not take into account age, immaturity, and understanding of the child offender when a judge considers applicable penalties and thus does not align with international standards.

\footnotetext{
50 Article 91 of the Old CPC.

Article 91 and 92 of the Old CPC.

See Pham 2015, p. 194.

Applicable only if it is not applied as a principal penalty.

Applicable only if it is not applied as a principal penalty.

Article 28(1)(2) of the Old PC.
} 
The New PC has broadened the application of non-custodial penalties. Of these, fines are applicable for less serious and serious crimes against people aged from 16 to 18 . Non-custodial reform can be applied to: (a) persons aged from 16 to 18 who have committed less serious, serious, or unintentionally very serious crimes; $(b)$ persons aged from 14 to 16 who intentionally have committed very serious crimes. Such penalties applied to juvenile offenders are no more than a half of the penalty which applies to adults for the same crime. ${ }^{56}$

Besides, the word 'only' in Article 71 might get judges tied up in cases where juvenile offenders are foreigners. Some argue that only four penalties are applicable, without including the possibility for expulsion of foreign juvenile offenders ${ }^{57}$ In other words, they interpret the word 'penalties' in the provision in the broadest sense, which cover both principal and additional penalties. The author's interpretation suggests a reading of the $\mathrm{PC}$ as a whole, arguing that the word 'penalties' is not specified. Consequently, it is possible to understand the word as either principal or additional penalties. However, all four types of penalties applicable to juvenile offenders above possess the same nature as other principal penalties, as provided in Article 28 of the Old PC. Therefore, it only indicates principal penalties and does not prevent the imposition of an additional penalty. As a result, expulsion can be imposed on foreign juvenile offenders as an additional penalty.

Nonetheless, the problem still remains in cases where the offenders are sentenced to termed imprisonment. It would be a huge challenge for the State of Vietnam to fulfill their right to education, health, religion, and family contact due to language and cultural barriers. The New PC or other laws do not shed light on this issue. Therefore, this still remains a challenge for the State of Vietnam when a foreign juvenile offender comes into conflict with Vietnamese law.

\subsection{The Right to be Heard}

Children's right to be heard is newly recognised as a general procedure-conducting principle in the New CPC. Hence, it is understood that the right is like a thread throughout all stages of the process, starting with the pre-trial stage where the child has the right to remain silent, as well as the right to be heard by the police, the public procurator and the investigating judge. Nevertheless, the practice of this right still remains questionable since the stipulation is rather general. Through her observation of the implementation of

56 Article 99, 100 of the New PC.

$57 \quad$ Dang and Hoang, Hoan Thien Quy Dinh cua Bo Luat Hinh Su ve Quyet Dinh Hinh Phat doi voi Nguoi Chua Thanh Nien Pham Toi [Suggestions for the Penal Code Regarding Deciding Penalties Against Juvenile Offenders], Tap chi Nha Nuoc va Phap Luat [Journal of State and Law] No. 5 (2014) pp. 72-78, at 72. 
the Old CPC in this regard, Nga Pham has found that 'juvenile offenders in Vietnam seem not to freely express their views' due to their lack of understanding, knowledge, and the fear of unknown consequences or of a suggested possibility of imprisonment. ${ }^{58}$ Therefore, this principle would be meaningless if authorities are not trained properly in handling children in conflict with the law.

\subsubsection{The Organisation of Juvenile Justice}

The Old PC and CPC have long established a separate chapter for special procedures dealing with offenders aged below 18. However, the general justice system and the juvenile justice system still overlap, and consequently the majority of general regulations of the PC and CPC are also applicable to juvenile offenders. The representative of the Supreme Court has admitted that there is no distinction in procedures between juvenile and adult cases. ${ }^{59}$

Currently, there are no specialised police forces or public procurators who are specifically trained to deal with juvenile offenders. As mentioned above, the New CPC has introduced the principle of best interest of the child and explicitly obligates procedure-conducting persons to be trained and obtain psychological and educational knowledge and experience before handling juvenile offenders. ${ }^{60}$ At present, a pilot child and juvenile-friendly investigation model is being launched with the support of international organisations in a number of provinces, in which it requires:

(i) Frequent training for police officers and investigators who have contact with juvenile offenders. Specialised police forces should be established to deal with issues connected to the juvenile offenders.

(ii) Where possible, taking down a statement from children and juveniles should be conducted at their home.

(iii) A juvenile-friendly investigation room should be created to suit the psychology of juveniles. During the interrogation, the police officers must be wearing civilian clothes.

58 Pham, Developments in the Right to Defence for Juvenile Offenders Since Vietnam's Ratification of the Convention on the Rights of the Child, U. of Pennsylvania East Asia Law Review, Vol. 9 (2014) pp.42-86, 83.

59 Tran, 'Nghien Cuu Thanh Lap Toa An Nguoi Chua Thanh Nien o Viet Nam' [Research on the Establishment of Juvenile Courts in Vietnam] in Toa An Nhan Dan Toi Cao [The People's Supreme Court] and UNICEF Vietnam (eds), Bao Cao Tong Quan ve Co So Ly Luan va Thuc Tien cua Su Can Thiet Thanh Lap Toa An Chuyen Trach doi voi Nguoi Chua Thanh Nien o Viet Nam [General Report on the Theoritical and Practical Rationale for Establishing Specialised Courts for Juveniles in Vietnam] (Thanh Nien, 2012), pp. 119-120.

60 Article 414 (1), 415 of New CPC. 
(iv) The place for custody and detention of juveniles should be improved to prevent detrimental impact on juveniles' psychology.

The identical problem has also existed within the court system. So far, there is neither professional judicial staff to deal with juvenile cases, nor a body of judges specialised in this field. ${ }^{61}$ The Jury Panel often lacks a teacher or a Youth Union cadre who understands the psychology of juveniles. ${ }^{62}$ The new Law on Courts of 2014 stipulates a system of family and juvenile courts that is organised from the central level to the district level, however, it has taken a long time to establish such court. Recently, the Supreme Court issued a decision to run a pilot family and juvenile court model in Ho Chi Minh city. ${ }^{63}$ Accordingly, it is recommended that:

(i) The courtroom should be decorated in a friendly manner to avoid juveniles' obsession of their illegal acts; the default setting is a closed hearing.

(ii) All the participants are required to wear casual clothes, including litigation-conducting persons; handcuffing of the juvenile offenders is restricted.

(iii) The language used during the trial must be comprehensible and understandable for juvenile offenders. ${ }^{64}$

On this matter, Vietnam regulations are already in line with the international standards, however it needs more time for pilot running and re-assessment on the practical basis in order to apply models on a larger scale.

\section{Conclusion}

Overall, a separate and independent juvenile justice system in Vietnam has yet to materialise. Currently, the juvenile justice provisions are incorporated into the general justice system. Most of the penal provisions apply equally to adults and to juveniles. However, this does not signify that the system lacks the capability to address juvenile offenders or that it fails to meet international standards in this regard.

The change in paradigm with regards to handling juvenile offenders, from a punitive to a restorative system, strengthens Vietnam's humane legislation and policies towards juvenile offenders. The MACR remains unchanged. The prohibition of death penalty and life imprisonment against juvenile offenders is to ensure children's right to life, survival

61 See People's Supreme Court and UNICEF Vietnam 2012 p. 40.

$62 \quad$ Ibid. pp. 119-120.

63 Thi Diem Toa An Gia Dinh Theo Mo Hinh The Gioi [Running A Pilot Family and Juvenile Court in Accordance with the World Model], ISL VASS, March 21 2016, Link: http://isl.vass.gov.vn/ noidung/vanban/Lists/GioiThieu/View_Detail.aspx?ItemID=78[Last accessed: July 14, 2016]. 
and development. Moreover, the introduction of leading principles and children's rights has proven Vietnam's endeavor in bringing its legislation into compliance with international standards. The Vietnam Government has managed to allocate adequate human, technical and financial resources to the protection and fulfillment of children's rights within juvenile justice to ensure a focus on diversion and other alternative measures to deprivation of liberty, and the provision of rehabilitation and reintegration programmes. These are very commendable and welcoming efforts. However, a number of challenges still remain; and the justice system is in need of further improvement.

First of all, the concept of a 'child' is still not in accordance with the recommendation by the CRC Committee, that is all persons under 18 years of age. ${ }^{65}$ The title of the New $\mathrm{PC}$ and CPC with regard to the treatment of juvenile offenders is changed into 'persons aged below 18 years'; and yet the 'best interest of the child' principle is introduced in this part. It implies that the lawmakers regard persons under the age of 18 as children. However, the fact that the definition of a child under the New Law on Care, Education and Protection of Children still remains unchanged, that is those aged below 16 years, is continuously confusing and problematic. It might reflect the inconsistency not only with the CRC, but also even within the national legal system. Hence, there is a need to review a number of regulations in this regard, such as the New Law on Care, Education and Protection of Children, with the purpose to bring Vietnam's legislations into conformity with international standards, as recommended by the CRC Committee.

Secondly, the best interest principle is introduced in the New PC. However, certain regulations, as pointed out above, are not consistent with the original spirit of the principle. Thus it is emphasised that the law enforcement and courts should prioritise the best interest principle in case they are on the fence about conflicting provisions in the PC and CPC.

Thirdly, in respect of foreign juvenile offenders, the State should initiate legal assistance treaties with other countries in this regard. Furthermore, diplomatic means and international cooperation in criminal matters can be a resort to solve the problem.

Fourthly, the practice of children's right to be heard is still very questionable, partially due to the organisations, personnels and authorities dealing with children in conflict with the law. The drawbacks and limitations of organisations working for or with children in conflict with the penal law have been shown. It has taken too long to initiate and run a pilot child-friendly investigation and court model. Meanwhile, social work center models, which have been built to provide residential care as an alternative to deprivation of liberty, are still far from effective.

Finally, the CRC Committee in its concluding observations has been concerned about the lack of adequate statistics and data collection regarding children in conflict with the 
penal law. ${ }^{66}$ The statistics in general reports on the crime situation and offenders are scattered, regarded not quite accurate and reliable, and sometimes even conflict with other available relevant statistics or case studies. There is no collaboration among agencies working with or for children and children in conflict with the law. ${ }^{67}$ This could lead to confusion when looking at and assessing the situation of juvenile offenders in Vietnam. Consequently, policy-makers need to pay attention and take more actions in this regard. 